jumping, facilitate provision of unnecessary and sometime dangerous medical procedures, siphon health care professionals from the public system, promote "cream skimming" (private clinics tend to handle less complex medical cases) and do not reduce wait times in public hospitals and clinics. Among the highlights of the report:

- Of the 42 private for-profit MRI/CT scan clinics in Canada, all but one were willing to sell medically necessary scans to patients for out-ofpocket fees, a violation of the Canada Health Act's prohibition on 2-tier medicine.

- Increasingly, private for-profit clinics that perform laser eye surgery (not deemed medically necessary) are also offering cataract surgery, a medically necessary procedure, for an out-of-pocket fee. In some cases, clinics charge the provincial health insurance plan and then also bill patients directly for cataract surgery.

- 72 private for-profit surgical hospitals were operating in 7 provinces in 2007. Almost half (34) of the hospitals told researchers they could buy medically necessary procedures, such as knee surgery, for out-ofpocket payments, and 31 said they did not charge patients for services. Meanwhile, only 2 provinces have accreditation processes that track these surgical hospitals.

- In 1993, Alberta became the first province to allow private for-profit MRIs but by 2001 the province was reversing the trend, and no new private MRI clinics were opened between 2003 and 2007. Instead, Alberta increased the capacity of the public system, and patients who had paid out-of-pocket for medically necessary scans were reimbursed by the province.

The report calls on provinces to set up monitoring and enforcement regimes for clinics that provide both medically necessary care (to ensure extra billing and queue jumping is not allowed), and medically unnecessary care (to ensure they don't stray into areas covered by the Canada Health Act). Ann Silversides, CMAJ

DOI:10.1503/cmaj.081690

\section{American entrepreneur files free trade challenge on medicare}

$\mathrm{A}$ n Arizona health care entrepreneur who believes anti-

American sentiment thwarted his plans to build a private surgical centre in British Columbia is seeking $\$ 155$ million in redress from the Canadian government, but a North American Free Trade Agreement expert claims the case is frivolous.

"I recruited people from around the world," says Melvin J. Howard, owner of Centurion Health Corporation. "They were all eager to come to BC. I had doctors from Switzerland, Spain, Paris. It was going to be kind of like the EU [European Union] of surgical centres."

On July 11, Howard, who along with about 200 financial backers claims to have incurred \$4 million in expenses during their failed effort to build a $\$ 150$ million surgical centre in Vancouver, $\mathrm{BC}$, filed a "notice of intent" to sue the Canadian government under Chapter 11 of the North American Free Trade breached 2 trade rules that protect the rights of US and Mexican parties to in-

In the claim, Howard writes (verbatim): "Centurion and its counter parties seek to be compensated for damages for barriers to entry and expropriation. ... Agreement. He claims Canada has vest in Canadian businesses.
Municipalities or city officials have put up numerous roadblocks such as zoning and by law requirements that is politically motivated instead of merit base. Its like saying yes you can no you can't in the same sentence ie. plausible deniability as far as the government is concerned."

"It's a shame he's going to get a year of free press," says T.J. Grierson-Weiler, an adjunct professor of law at the University of Western Ontario who has worked on dozens of international treaty cases.

The first problem with Howard's notice, says Grierson-Weiler, is the use of the word "expropriation." A valid expropriation case can only be made under the trade agreement when a government takes something (land, buildings, intellectual property) from a foreign investor. Construction hadn't begun on the proposed British Columbia surgical centre so that doesn't apply, says Grierson-Weiler. "What's been taken besides his aspirations?"

Another problem is that much of Howard's argument appears to be based on the inconsistencies in health care delivery between provinces. In his notice of intent, Howard mentions recent private health care initiatives in Alberta and Quebec, which implies, says Grierson-Weiler, that he is seeking equally favourable

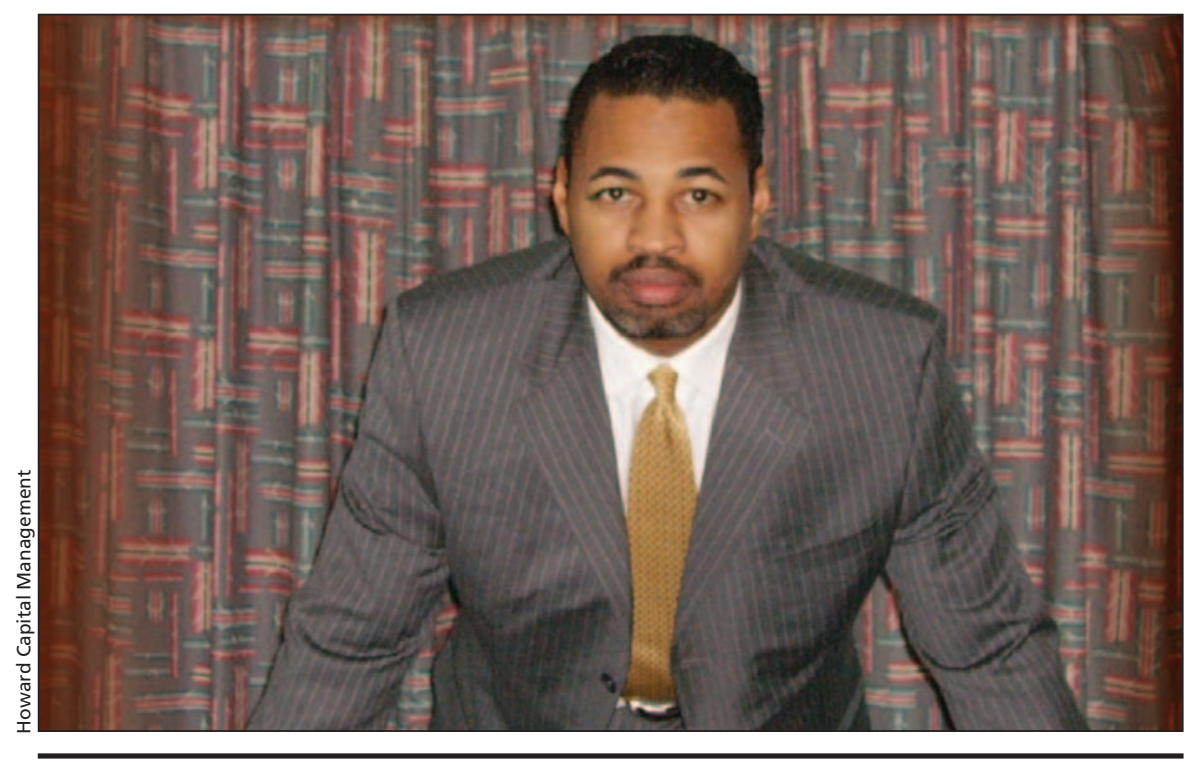

Centurion Health Corporation owner Melvin J. Howard is seeking \$155 million in redress from Canada for an alleged violation of the North American Free Trade Agreement. 
treatment in British Columbia. But under the trade agreement, a party cannot seek better treatment in one jurisdiction because it is offered in another.

In a post on worldtradelaw.typepad .com, Grierson-Weiler expressed his concern that these types of cases attract too much attention: "Such stories don't just provide some modicum of credibility for manifestly incredulous legal claims; they reinforce commonly-held beliefs about the sacred quality of a method of socialised medicine that verge upon some sort of political existentialism."

Dr. Danielle Martin, chair of Canadian Doctors for Medicare, is not so quick to dismiss Howard's attack on Canada's health care system. With more and more private health care providers opening shop in Canada, pressure from US investors is inevitable, she says. "The threat is real. ... If it's not him, it will probably be someone else. Once the big guys come in, we'll have real problems."

Howard believes his case is strong because circumstances have changed since the trade agreement came into effect. "In 1994, the government maybe had a case that medicare was grandfathered in, but today, in 2008, the medicare program has eroded. There are private centres all around." He also claims many Canadian politicians encouraged his plans in private but distanced themselves from him in public. As well, Howard wants the issue of US investment in Canadian health care brought into the open.

"It involves much more than just making a profit. I want Canadians to have the best care, and they can't get that under the status quo. But mainly I'm doing this because I've had enough of the hypocrisy."

Even if he fails to get a penny from the Canadian government, Howard says he will continue to look for ways to invest in Canadian health care. "I'm not done with Canada. I know that I can bring a lot more in terms of health care services to Canada. I have family and friends there, and I'm not going to abandon them because the government can't decide who it wants to be." - Roger Collier, CMAJ

DOI: $10.1503 / \mathrm{cmaj} .081703$

\section{Federal election wrap: medical profession to be sparsely represented in House of Commons}

Published at www.cmaj.ca on Oct. 17, 2008

$\mathrm{I}$ f economics truly is "the dismal science," then voters might well be tempted to conclude that politics is the dismal art.

As Canadians trekked to the polls on Oct. 14 to make their choices in the 40th general election, pollsters warned that all those voters seemed singularly unimpressed with their options - party leaders were largely uninspiring; campaigns lacklustre and strategies mediocre, if not incoherent. All parties seemed resolutely determined to avoid issues like health care. In fact, it barely made a ripple in the political pond throughout the 5-week campaign despite being consistently rated as a major public concern.

Small wonder, then, that many eligible voters did not make the trek, resulting in a historic low turnout of $59 \%$ as Prime Minister Stephen Harper and the governing Conservatives garnered 143 seats and earned their second consecutive minority. The Liberals plummeted to 76. The Bloc Quebecois held at 50, while the New Democrats rose to 37. The Green Party was shut out, while 2 independents were elected.
Within that mix lies another harsh reality: the medical community will continue to be sparsely represented within Parliament.

There were 4 physicians in the House of Commons when it was dissolved. There will be 4 in the new Parliament - in fact, the same 4 stalwarts as in the previous one. All are Liberals and all are general practitioners:

- Dr. Carolyn Bennett (St. Paul's)

- Dr. Hedy Fry (Vancouver Centre)

- Dr. Keith Martin (Esquimalt Juan De Fuca)

- Dr. Bernard Patry (Pierrefonds Dollard).

It will be Bennett's fifth term in the House, while Martin, Fry and Patry have now successfully run 6 times.

Eleven other physicians who sought office saw their political aspirations scuttled:

- Dr. Pierre Gfeller, general practitioner, Liberal (Laurentides-Labelle)

- Dr. Qais Ghanem, neurophysiologist, Green Party (Ottawa South)

- Dr. Sean Godfrey, pediatrician, Liberal (Oshawa)

- Dr. Gordon Guyatt, professor, McMaster University Department of

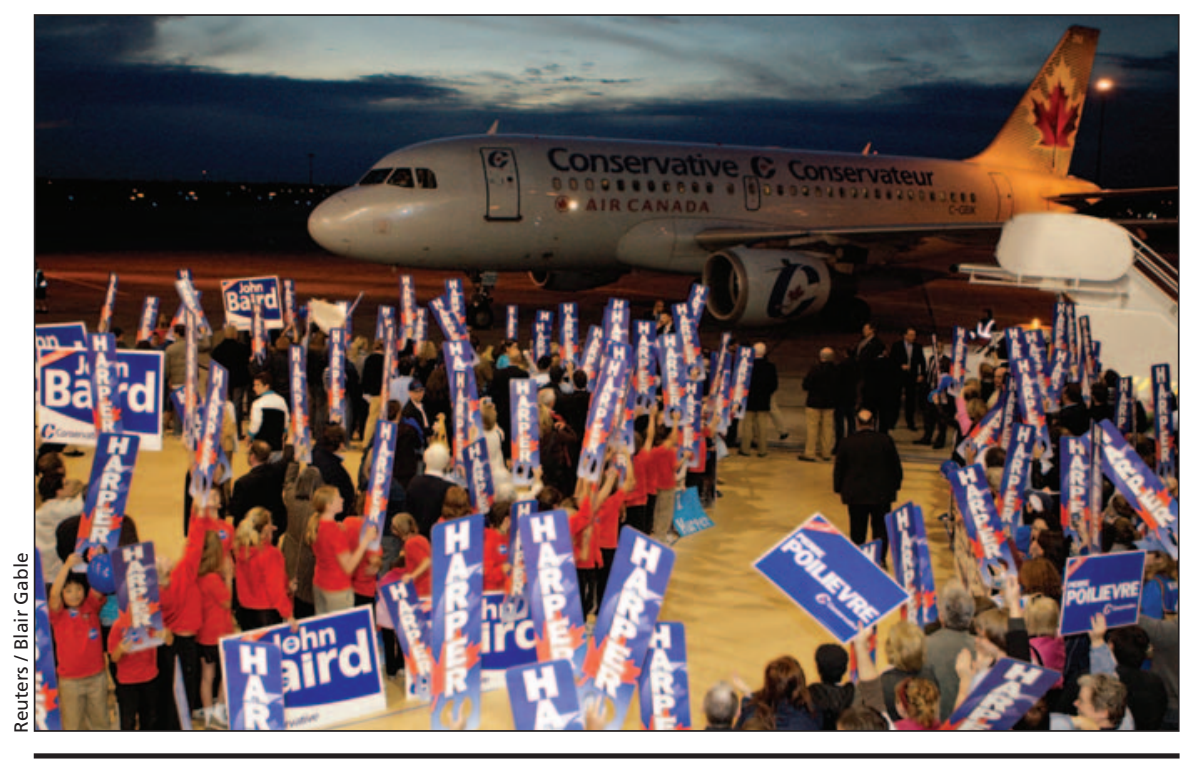

Re-elected Prime Minister Stephen Harper arrives at the Canada Reception Centre in Ottawa, Ontario, a day after his Conservatives captured their second consecutive minority. 